\title{
DAMPAK EKONOMI DAN SOSIAL ALIH FUNGSI LAHAN PERTANIAN HORTIKULTURA MENJADI KAWASAN WISATA BUKIT RURUKAN DI KECAMATAN TOMOHON TIMUR, KOTA TOMOHON
}

\author{
Elisabeth Ante \\ Noortje M. Benu \\ Vicky R.B Moniaga
}

\begin{abstract}
This research aims is to describe the impact of Horticulture land conversion to farmer's economy condition and socio-cultural condition that has sold their land to be made into tourist attraction. Research carried out in May until July 2016. Data used is primary data that obtained from interview to 6 (six) respondents and secondary data obtained from Rurukan Office village. Research result shows that the cause of land conversion is high offer price and the sale of land used for opening business in the tourist attraction. the positive impact of land conversion one of them is employment, because the majority of workers and businessman in the tourist attraction is from Rurukan village. Research result also identifying negative impact to locals because of the noises from tourist attraction and the disappearing of local's cultures.
\end{abstract}

Keywords: social economy impact, land function change, East Tomohon Sub-district, Tomohon City.

\begin{abstract}
ABSTRAK
Penelitian ini bertujuan untuk mendeskripsikan dampak alih fungsi lahan pertanian terhadap kondisi ekonomi dan kondisi social-budaya petani yang telah menjual lahan pertaniannya untuk dijadikan Obyek Wisata. Penelitian dilaksanakan pada bulan Mei sampai Juli 2016. Data yang digunakan adalah data primer yang diperoleh melalui wawancara kepada 6 (enam) orang responden dan data sekunder diperoleh dari Kantor Desa Kelurahan Rurukan. Hasil penelitian menunjukan bahwa terjadinya konversi lahan dipengaruhi oleh harga lahan yang tinggi dan hasil penjualan lahan dimanfaatkan responden untuk membuka usaha dilokasi wisata. Dampak positif akibat alih fungsi lahan salah satunya penyerapan tenaga kerja, karena mayoritas pekerja dan pelaku usaha di kawasan wisata adalah masyarakat yang berasal dari Desa Rurukan. Hasil penelitian juga mengidentifikasi adanya dampak negatif terhadap masyarakat karena sering terjadi keributan di lokasi wisata dan terkikisnya norma-norma masyarakat dengan adanya budaya luar yang bertentangan dengan budaya lokal masyarakat.
\end{abstract}

Kata Kunci: dampak ekonomi sosial, alih fungsi lahan, Kecamatan Tomohon Timur, Kota Tomohon.

\section{PENDAHULUAN}

\section{Latar Belakang}

Perkembangan suatu daerah ditentukan oleh potensi andalan dan unggulan yang dapat dijadikan sumber pendapatan asli daerah. Pembangunan sebagai sarana untuk meningkatkan taraf hidup dan mutu masyarakat tidak hanya terbatas pada sektor ekonomi saja, tetapi meliputi seluruh aspek kehidupan termasuk didalamnya kebutuhan akan rekreasi
(Paramitasari, 2010). Indonesia merupakan sebuah negara tropis yang memiliki banyak lokasi pariwisata, yang didukung oleh kekayaan alam yang melimpah. Pariwisata adalah salah satu sektor yang cukup memiliki peluang besar, karena menjadi salah satu penghasil pertumbuhan ekonomi. Hal inilah yang mendorong pemerintah terus melaksanakan pembangunan di sektor Pariwisata (Putra, 2013). 
Pariwisata terbagi dua bagian yakni pariwisata buatan dan pariwisata alami. Sebagai negara agraris, Indonesia memiliki kekayaan alam dan hayati yang sangat beragam, yang jika dikelola dengan tepat, maka perpaduan antara keindahan alam, kehidupan masyarakat pedesaan dan potensi pertanian, dapat mengembangkan daya tarik wisata bagi satu daerah tujuan wisata (Mandiangan, 2007). Banyak pariwisata di Indonesia yang dibangun dengan memanfaatkan sumber daya alam sebagai pariwisata alami, seperti suasana pertanian. Berkurangnya lahan yang dapat dimanfaatkan sebagai kawasan wisata di pedesaan, mengakibatkan perkembangan pariwisata yang memanfaatkan nuansa pertanian justru mengakibatkan alih fungsi lahan pertanian ke non pertanian, yang dalam hal ini menjadi industri pariwisata.

Alih fungsi lahan ini juga dikarenakan potensi Indonesia yang berbasis pertanian, dengan kekayaan sumber daya alam yang melimpah, mendorong pihak-pihak tertentu untuk memperoleh keuntungan dengan mengubah lahan pertanian menjadi sarana pariwisata. Faktor yang berperan penting yang menyebabkan proses konversi lahan pertanian ke non pertanian menurut Nasoetion, (2000) adalah perkembangan standar tuntutan hidup, fluktuasi harga pertanian, struktur biaya produksi pertanian, teknologi, aksesibilitas, resiko dan ketidakpastian dalam pertanian. Lahan pertanian dapat memberikan banyak manfaat seperti dari segi ekonomi, sosial, dan lingkungan. Namun, akibat konversi lahan yang menjadikan semakin sempitnya lahan pertanian akan mempengaruhi segi ekonomi, sosial, dan lingkungan tersebut. Jika konversi lahan pertanian ke non pertanian ini terus dilakukan dan tidak terkendali, maka hal ini tidak hanya menjadi masalah bagi petani di daerah, tetapi hal ini bisa menjadi masalah nasional bangsa Indonesia (Dwipradnyana, 2014).

Sulawesi Utara, merupakan salah satu Provinsi yang menjadi sentra pertanian yang terus mengalami perkembangan pariwisata, yang mengakibatkan alih fungsi lahan. Salah satu kawasan pariwisata yang saat ini sementara berkembang adalah Puncak Rurukan yang terletak di Desa Rurukan, Kelurahan Rurukan, Kecamatan Tomohon Timur, kota Tomohon. Desa ini berada didataran tinggi, yang memiliki suhu yang sejuk dan memiliki potensi pariwisata yang menarik dalam bidang pertanian seperti, pemandangan alam yang indah dengan lahan pertanian hortikultura yang tersusun rapi, membentuk pemandangan yang indah, yang dijadikan daya tarik terhadap kawasan obyek wisata Bukit Rurukan

\section{Pengertian dan Fungsi Utama Lahan}

Menurut Mamarodia (2014), lahan merupakan sumberdaya pembangunan yang memiliki karakteristik ketersediaan atau luasnya relatif tetap karena perubahan luas akibat proses alami (sedimentasi) dan proses artifisial (reklamasi) sangat kecil. Bagi petani lahan adalah tempat bercocok tanam dan sumber kehidupan, sedangkan bagi penduduk perkotaan lahan adalah ruang untuk mendirikan bangunan seperti rumah, toko dan lain sebagainya.

Perbedaan pemahaman lahan antara penduduk kota dan petani disebabkan oleh perkembangan modernisasi yang terus terjadi di area perkotaan, yang menggeser budaya dan kebiasaan masyarakat Indonesia, yang sejak dulu terkenal didunia karena potensi pertaniannya. Keberlanjutan sektor pertanian tengah dihadapkkan pada ancaman serius,yakni luas lahan pertanian yang terus menyusut akibat alih fungsi lahan pertanian produktif ke penggunaan non-pertanian yang terjadi secara terus-menerus (Wahyunto, 2001)

Kini lahan pertanian lebih menguntungkan untuk dijadikan sebagai real estate, pabrik atau infrastruktur untuk aktivitas industri lainnya, dari pada ditanami tanaman holtikultura. Lahan sebagai salah satu faktor produksi merupakan sumber hasilhasil pertanian yang menjadi tempat proses produksi dan hasil produksi diperoleh. Bagi petani, lahan mempunyai arti yang sangat penting karena dari lahan mereka dapat mempertahankan hidup bersama keluarganya melalui kegiatan bercocok tanam (Dwipradnyana, 2014).

\section{Alih Fungsi Lahan}

Menurut Lestari , (2009) alih fungsi lahan atau lazimnya disebut sebagai konversi lahan adalah perubahan fungsi sebagian atau seluruh kawasan lahan dari fungsinya semula (seperti yang direncanakan) menjadi fungsi lain 
yang dapat mengakibatkan dampak negatif (masalah) terhadap lingkungan dan potensi lahan itu sendiri. Irawan, (2005) juga berpendapat bahwa konversi lahan merupakan ancaman yang serius bagi keberlanjutan fungsi lahan untuk pertanian, dan pada akhirnya juga akan berdampak terhadap ketahanan pangan nasional karena dampak perubahannya bersifat permanen.

Berdasarkan teori di atas dapat ditarik kesimpulan bahwa alih fungsi lahan pertanian adalah pengalokasian sumberdaya lahan dari satu penggunaan ke penggunaan lainnya. Irawan (2004) mengungkapkan bahwa konversi lahan berawal dari permintaan komoditas pertanian terutama komoditas pangan yang kurang elastis terhadap pendapatan dibanding permintaan komoditas non-pertanian. seperti dalam UU No. 41 Tahun 2009 tentang perlindungan lahan pangan berkelanjutan menyebutkan bahwa lahan pertanian berkelanjutan adalah bidang lahan pertanian yang ditetapkan untuk dilindungi dan dikembangkan secara knsisten guna menghasilkan pangan pokon bagi kemandirian, ketahanan, dan kedaulatan pangan nasional. Oleh karena itu, pembangunan ekonomi yang berdampak pada peningkatan pendapatan penduduk cenderung menyebabkan naiknya permintaan komoditas non pertanian dengan laju lebih tinggi dibanding permintaan komoditas pertanian.

Konsekuensi lebih lanjut adalah, karena kebutuhan lahan untuk memproduksi setiap komoditas merupakan turunan dari permintaan komoditas yang bersangkutan, maka pembangunan ekonomi yang membawa kepada peningkatan pendapatan akan menyebabkan naiknya permintaan lahan untuk kegiatan di luar pertanian dengan laju lebih cepat dibanding kenaikan permintaan lahan untuk kegiatan pertanian.

\section{Faktor Penyebab Alih Fungsi Lahan Pertanian menjadi Non-Pertanian}

Menurut Lestari (2009), terjadinya proses alih fungsi lahan pertanian ke penggunaan non pertanian dapat disebabkan oleh beberapa faktor. Disebutkan ada tiga faktor penting yang menyebabkan terjadinya alih fungsi lahan pertanian yaitu sebagai berikut:

1. Faktor eksternal merupakan faktor yang disebabkan oleh adanya dinamika pertumbuhan daerah perkotaan, demografi maupun ekonomi.

2. Faktor internal di mana faktor ini jauh lebih melihat sisi yang disebabkan oleh kondisi sosial - ekonomi rumah tangga pertanian pengguna lahan.

3. Faktor kebijakan merupakan aspek regulasi yang dikeluarkan oleh pemerintah pusat maupun daerah yang berkaitan dengan perubahan fungsi lahan pertanian. Kelemahan pada aspek regulasi atau peraturan itu sendiri terutama terkait dengan masalah kekuatan hukum, sanksi pelanggaran dan akurasi objek lahan yang dilarang konservasi.

Pada dasarnya penggunaan lahan di beberapa daerah adalah sebuah refleksi dari kompetisi antara beberapa penggunaan yang bervariasi yang operasionalnya melalui kekuatan demand dan supply, perubahan penggunaan lahan merupakan bentuk respon terhadap permintaan lahan yang terus meningkat karena supply lahan tetap (Raharjo, 1999). Sedangkan, menurut Wahyunto (2001), perubahan penggunaan lahan dalam pelaksanaan pembangunan tidak dapat dihindari. Perubahan tersebut terjadi karena dua hal, pertama adanya keperluan untuk memenuhi kebutuhan penduduk yang makin meningkat jumlahnya dan kedua berkaitan dengan meningkatnya tuntutan akan mutu kehidupan yang lebih baik.

Irawan (2005) menyebutkan ,ada dua hal yang mempengaruhi alih fungsi lahan . Pertama, sejalan dengan pembangunan kawasan perumahan atau industri di suatu lokasi alih fungsi lahan, maka aksesibilitas di lokasi tersebut menjadi semakin kondusif untuk pengembangan industri dan pemukiman yang akhirnya mendorong meningkatnya permintaan lahan oleh investor lain atau spekulan tanah sehingga harga lahan di sekitarnya meningkat. Kedua, peningkatan harga lahan selanjutnya dapat merangsang petani lain di sekitarnya untuk menjual lahan.

\section{Dampak Alih Fungsi Lahan}

Menurut Priyono, (2012) dampak alih fungsi lahan pertanian, yaitu :

a) Dengan adanya alih fungsi lahan maka secara langsung memusnahkan lahan 
pertanian yang mengakibatkan semakin menyempitnya lahan pertanian, berkurangnya pendapatan petani, bahkan menghilangkan mata pencaharian buruh tani.

b) Dengan adanya kebijakan pemerintah, yang sebagian besar lahan yang di gunakan merupakan areal pertanian, maka hal tersebut tentunya menimbulkan sentimen masyarakat terhadap pemerintah, karena pemerintah dianggap tidak memikirkan kehidupan masyarakat petani.

Dampak konversi lahan pertanian menyangkut berbagai dimensi kepentingan yang luas yaitu tidak hanya mengancam keberlanjutan swasembada pangan, tetapi juga berkaitan dengan penyerapan tenaga kerja, pemubaziran investasi irigasi, pemerataan kesejahteraan, kualitas lingkungan hidup dan kemapanan struktur sosial masyarakat (Dwipradnyana, 2014). Dampak-dampak tersebut akan mengakibatkan kerugian bagi daerah, petani, masyarakat bahkan pemerintah, karena Berdasarkan data rencana Strategi Kementrian Pertanian (Restra Kementan) Tahun 2015-2019, menyebutkan Kementrian Pertanian hanya bisa mencetak lahan baru seluas 330 hektar selama 2006-2013 atau seluas 40 ribu ha per tahunnya. Kemampuan cetak sawah belum bisa menyamai laju konversi lahan sawah seluas 100 hektar per tahun. Salah satunya adalah keterbatasan anggaran yang dimiliki pemerintah, karena untuk mencetak 1 hektar lahan dibutukan dana sekitar 30 juta rupiah.

\section{Pariwisata}

Pengertian pariwisata dilihat dalam Undang-undang Indonesia No. 10 Tahun 2009, tentang kepariwisataan dalam pasal 1 menyatakan :

1. Wisata adalah kegiatan perjalanan yang dilakukan oleh seseorang atau sekelompok orang dengan mengunjungi tempat tertentu untuk tujuan rekreasi, pengembangan diri, atau mempelajari keunikan daya tarik wisata yang dikunjungi dalam jangka waktu sementara.

2. Wisatawan adalah orang yang melakukan wisata.

3. Pariwisata adalah berbagai macam kegiatan wisata dan didukung berbagai fasilitas serta pelayanan yang disediakan oleh masyarakat, pengusaha, Pemerintah, dan Pemerintah Daerah.

4. Kepariwisataan adalah keseluruhan kegiatan yang terkait dengan pariwisata dan bersifat multidimensi serta multidisiplin yang muncul sebagai wujud kebutuhan setiap orang dan negara serta interaksi antara wisatawan dan masyarakat setempat, sesama wisatawan, Pemerintah, Pemerintah Daerah, dan pengusaha.

5. Daya tarik wisata adalah segala sesuatu yang memilimi keunikan, keindahan, dan nilai yang berupa keanekaragaman kekayaan alam, budaya dan hasil buatan manusia yang menjadi sasaran atau tujuan kunjungan wisatawan.

6. Daerah tujuan pariwisata yang selanjutnya disebut Destinasi Pariwisata adalah kawasan geografis yang berada dalam satu atau lebih wilayah administratif yang di dalamnya terdapat daya tarik wisata, fasilitas umum, fasilitas pariwisata, aksesbilitas, serta masyarakat yang saling terkait dalam melengkapi terwujudnya pariwisata.

7. Usaha Pariwisata adalah usaha yang menyediakan baran dan/ atau jasa bagi pemenuhan kebutuhan wisatawan dan penyelenggara pariwisata.

8. Pengusaha pariwisata adalah orang atau sekelompok orang yang melakukan kegiatan usaha pariwisata.

Berdasarkan uraian tersebut, dapat diambil kesimpulkan bahwa pariwisata adalah perjalanan yang dilakukan oleh seseorang untuk menikmati obyek atau daya tarik wisata, yang sifatnya sementara dan memberi kepuasan.

\section{Dampak Perkembangan Pariwisata}

Menurut kamus Besar Bahasa Indonesia dampak dapat diartikan sebagai pengaruh kuat yang ditimbulkan dan dapat mendatangkan akibat (baik positif maupun negatif). Perkembangan adalah suatu usaha meningkatkan kemampuan teknis, teoritis, konseptual, dan moral sesuai kebutuhan melalui pendidikan dan pelatihan. Alasan utama perkembangan daerah pariwisatata, sangat erat hubungannya dengan pembangunan ekonomi didaerah tersebut (Wibowo, 2007). Pariwisata merupakan 
industri yang mampu memberikan manfaat langsung maupun tidak langsung kepada pemerintah dan masyarakat. Namun, apabila tidak di cermati/di waspadai secara baik akan merusak tatanan/ nilai-nilai kehidupan masyarakat. Masyarakat lokal memiliki peran yang penting dalam keberlangsungan kehidupan tempat wisata itu sendiri karena obyek wisata tersebut dapat mempengaruhi kehidupan mereka baik dalam kondisi lingkungan, sosial maupun ekonomi. Adapun dampak perkembangan pariwisata menurut Mill dalam Paramitasari, (2010) diuraikan sebagai berikut

\section{Dampak Segi lingkungan}

Dampak Lingkungan yang terjadi, dapat bersifat positif yaitu memelihara lingkungan, ataupun dapat bersifat negatif seperti merusak lingkungan. Salah satu faktor yang menentukan positif atau negatif dampak yang terjadi terhadap lingkungan di pengaruhi oleh kerjasama antara masyarakat lokal yang berada di sekitar kawasan wisata, pemerintah Desa setempat dan pihak pengelolah wisata dalam menjaga kelestarian alam sekitar kawasan wisata.

\section{Dampak Sosial Budaya}

Dampak ini sering disebut sebagai dampak negatif dari perkembangan pariwisata. Hal ini disebabkan oleh banyaknya wisatawan yang berasal dari luar daerah dan membawa kebiasaan yang dapat mempengaruhi kebudayaan masyarakat lokal. Namun, jika banyaknya wisatawan yang ada dijadikan peluang mempromosikan kebudayaan, dapat memberikan dampak positif terhadap kehidupan sosial budaya masyarakat lokal.

\section{Dampak Ekonomi}

Dampak ekonomi dapat bersifat negatif atau positif. Hal ini ditentukan oleh petani bahkan masyarakat sekitar kawasan wisata dalam memanfaatkan peluang yang ada dengan sebaik-baiknya.

\section{Dampak terhadap Pertanian}

Menurut Muflihati, (2013) beberapa dampak negatif dari perkembangan pariwisata, yaitu :
1. Laju alih fungsi lahaan pertanian menjadi non pertanian akan semakin tinggi

2. Penurunan mutu lahan pertanian akibat pengelolaan yang kurang tepat

3. Minat generasi muda berprofesi dibidang pertanian menurun

4. Pencitraan pertanian yang kurang tepat

5. Apresiasi masyarakat pada pertanian melemah

6. Nilai tukar produk pertanian rendah

7. Tingkat pendidikan masyarakat relatif rendah.

Sedangkan, dampak positif dari perkembangan pariwisata bagi pertanian terutama dikawasan hortikultura, yakni :

1. Meningkatnya konservasi lingkungan tanaman hortikultura akan memberi mempengaruhi cuaca bahkan iklim disekitarnya. Hal ini membuat produk wisata, tidak harus berupa obyek alam, akan tetapi inovasi terhadap hasil pertanian dapat meningkatkan jumlah wisatawan

2. Meningkatkan estetika dan keindahan alam, lingkungan alam yang indah, panorama yang akan memberikan kenyamanan dan tertata rapi, akan memberikan nuansa alam yang membuat terpesona orang yang melihatnya. Bangunan yang didesain dapat menyatu dengan alam, itulah yang selalu diharapkaan dalam perkembangan pariwisata didaerah pertanian

3. Memberikan nilai rekreasi, perpaduan antara kegiatan rekreasi dengan pemanfaatan hasil pertanian, maka dapat dikembangkan nilai ekonomis dengan menjual hasil tanaman hortikultura kepada pengunjung.

\section{Faktor Sosial-Ekonomi Petani}

Faktor sosial ekonomi adalah faktorfaktor yang berasal dari segi sosial dan ekonomi yang dimiliki petani sehingga dapat mempengaruhi mereka mengenai suatu hal. Petani adalah semua orang yang berdiam di perdesaan yang mengelola usaha pertanian (Wulandari, 2013). Menurut Hartanto (1984), karakteristik sosial-ekonomi petani meliputi : 


\section{Umur}

Umur petani akan mempengaruhi kemampuan fisik dan respon terhadap hal-hal yang baru dalam menjalankan usaha taninya. Menurut Kartasapoetra (1991), petani yang berusia lanjut akan sulit untuk diberikan pengertian yang dapat mengubah cara berfikir, cara kerja dan cara hidup. Umur petani akan mempengaruhi kemampuan fisik dan respon terhadap hal-hal yang baru dalam menjalankan usaha taninya. Sebagian besar petani di Indonesia berumur sekitar 25 sampai 45 tahun, semakin muda petani, biasanya mempunyai semangat ingin mengetahui yang belum mereka ketahui.

\section{Tingkat pendidikan}

Mardikanto

menerangkan pendidikan merupakan proses timbal balik dari setiap pribadi manusia dalam penyesuaian dirinya dengan alam, teman dan alam semesta. Sedangkan Suhardiyono (1992) menjelaskan bahwa para ahli pendidikan mengenal 3 sumber pengetahuan, yaitu :

a. Pendidikan Informal : proses pendidikan yang panjang, diperoleh daan dikumpulkan oleh seseorang berupa pengetahuan, keterampilan, sikap hidup, dan segala sesuatu yang diperoleh dari pengalaman pribadi sehari-hari dari kehidupannya dalam masyarakat.

b. Pendidikan Formal : struktur dari suatu sistem pengajaran yang kronologis dan berjenjang lembaga pendidikan mulai dari pra sekolah sampai dengan perguruan tinggi.

c. Pendidikan Non-formal : pengajaran sistematis yang diorganisir dari luar sistem pendidikan formal bagi sekelompok orang untuk memenuhi keperluan khusus. Salah satu contoh pendidikan non-formal ini adalah penyuluhan pertanian.

Pendidikan dapat diperoleh melalui pendidikan informal, formal maupun nonformal, keterbatasan pengetahuan yang dimiliki petani biasanya akan menjadi hambatan. Tingkat pendidikan petani baik informal, formal maupun non formal akan mempengaruhi cara berfikir yang diterapkan pada usahanya yaitu dalam rasionalisasi usaha dan kemampuan memanfaatkan setiap kesempatan yang ada.

\section{Pendapatan}

Pendapatan merupakan faktor yang sangat penting dalam menunjang perekonomian keluarga. Tingkat pendapatan merupakan salah satu indikasi sosial ekonomi seseorang dalam masyarakat di samping pekerjaan, kekayaan dan pendidikan. Keputusan seseorang dalam memilih pekerjaan dipengaruhi oleh sumberdaya dan kemampuan dalam diri individu.

\section{Luas Penguasaan Lahan}

Menurut Rahardjo (1999) pemilikan lahan yang sempit cenderung pada sistem pertanian intensif. Sedang pada lahan yang luas cenderung kepada ekstensif. Selain lahan memiliki fungsi produksi, lahan (tanah) juga dapat digunakan untuk meminjam uang di bank. Selain itu, lahan yang luas dan usaha tani komersil, berpotensi membutuhkan modal yang lebih besar sehingga kebutuhan akan kredit semakin besar pula. Sebagai sumber ekonomi bagi masyarakat desa khususnya petani, luas lahan dan kondisi sawah sebagai lahan pertanian sangat menentukan produksi dan pendapatan rumah tangga petani (Mardikanto, 1993).

5. Modal dan Pengalaman

Pengalaman menunjukkan bahwa interaksi yang terjadi cenderung akan mengakibatkan dan menghasilkan adanya diri yang timbal balik serta penyesuaian kecakapan dengan situasi baru. Menurut Mill (dalam Paramitasari, 2010) modal adalah barang atau jasa yang dipakai untuk menghasilkan produk. Modal dapat dibagi dua yaitu modal tetap merupakan modal yang tidak habis dalam satu kali proses produksi. Dan modal tidak tetap, yaitu modal yang habis dipakai dalam satu kali proses produksi.

6. Tenaga Kerja

Tenaga kerja (Man Power) adalah jumlah seluruh penduduk dalam suatu negara yang dapat memproduksi barang-barang dan jasa-jasa. Menurut Hartanto (1984) tenaga kerja terdiri dari dua kata tenaga dan kerja. Dimana tenaga adalah banyaknya usaha yang dikeluarkan dalam tiap ssatuan waktu, sedangkan kerja adalah banyaknya tenaga yang dikeluarkan dalam suatu kurun waktu untuk menghasilkan suatu jumlah efek.

7. Jumlah tanggungan

Banyaknya anggota dalam keluarga akan menentukan cara pengelolaan suatu usahatani. Jumlah anggota keluarga yang terlalu 
banyak akan menyebkan biaya yang dikeluarkan untuk konsumsi makin besar, sehingga tidak tersisa untuk biaya pengelolaan pertanian ( Raharjo, 1999)

\section{Perumusan Masalah}

Berdasarkan latar belakang maka perumusan masalah pada penelitian adalah bagaimana dampak alih fungsi lahan pertanian hortikultura terhadap kondisi ekonomi dan kondisi sosial budaya petani yang telah menjual lahan pertanian untuk dijadikan Obyek Wisata.

\section{Tujuan dan Manfaat Penelitian}

Berdasarkan masalah yang telah dikemukakan maka tujuan penelitian ini, yaitu mendeskripsikan dampak alih fungsi lahan pertanian hortikultura terhadap kondisi ekonomi dan sosial budaya petani yang telah menjual lahan pertanian untuk dijadikan Obyek Wisata. Memberikan manfaat informasi yang berguna tentang adanya dampak sosial ekonomi alih fungsi lahan pertanian hortikultura.

\section{METODOLOGI PENELITIAN}

\section{Waktu dan Tempat Penelitian}

Penelitian ini telah dilaksanakan selama 3 (tiga) bulan mulai dari persiapan hingga penyusunan laporan. Pemilihan lokasi penelitian dilakukan secara sengaja (purposive), yaitu di Kelurahan Rurukan, Kecamatan Tomohon Timur, Kota Tomohon.

\section{Metode Pengambilan Sampel}

Teknik pengambilan sampel adalah Purposive Sampling yaitu pengambilan sampel berdasarkan ciri-ciri tertentu, yaitu responden adalah delapan (8) keluarga yang telah menjual lahan pertanian holtikultura untuk dialih fungsikan menjadi Obyek Wisata Bukit Rurukan.

\section{Metode Pengumpulan Data}

Data yang dikumpulkan dalam penelitian ini adalah data primer dan data sekunder. Data primer adalah data yang diperoleh melalui wawancara pada petani yang telah menjual lahan untuk dialihfungsikan. Sementara data sekunder adalah data yang diperoleh melalui dokumentasi dari instansi- instansi yang berkaitan dengan penelitian ini antara lain kantor kelurahan Rurukan.

\section{Konsep Pengukuran Variabel}

Variabel Penelitian :

Indikator yang akan digunakan untuk mengetahui dampak terhadap petani yang mengalih fungsikan lahan pertanian hortikultura mereka menjadi obyek wisata, adalah sebagai berikut :

1. Dampak Ekonomi dilihat dari :

- aspek pendapatan,

- penyerapan tenaga kerja, dan

- peluang berusaha.

2. Dampak Sosial Budaya dilihat dari :

- Peningkatan pelestarian tradisi dan kesenian tradisional

- Perubahan mata pencaharian

- $\quad$ Tingkat kriminalitas

\section{Metode Analisis Data}

Tahap analisis data bertujuan untuk mengetahui dampak alih fungsi lahan terhadap kondisi ekonomi dan sosial budaya dari responden. Teknik analisis data yang digunakan adalah teknik analisis data deskriptif dengan menggunakan tabel yang mudah dimengerti dan diinterpretasikan, serta menyusun dan menyajikan data menjadi informasi yang jelas.

\section{HASIL DAN PEMBAHASAN}

\section{Deskripsi Lokasi Penelitian}

Kelurahan Rurukan memiliki jarak dengan kecamatan $5000 \mathrm{M}$, jarak dengan ibukota kabupaten/kota $6000 \mathrm{M}$, dan jarak dengan ibukota provinsi 30.000 M. Kelurahan Rurukan berada pada ketinggian 1100-1300 mdpl (meter diatas permukaan laut). Lahan ini memiliki luas \pm 350 hektar dan terdiri atas 10 jaga. Batas-batas wilayah administratif Kelurahan Rurukan sebagai berikut :
Utara
: Kelurahan Kumelembuay
Timur
: Rurukan Satu
Selatan
: Kabupaten Minahasa
Barat
: Talete Satu dan Paslaten Satu

\section{Faktor-Faktor Terjadinya Konversi Lahan Pertanian Menjadi Non-Pertanian}

Seperti yang dikemukakan oleh Lestari, (2009) bahwa faktor penyebab alih fungsi lahan 
pertanian ke non-pertanian dapat disebabkan oleh beberapa faktor, yaitu :

\section{Faktor Eksternal}

Menurut Priyono, (2011) Faktor eksternal merupakan faktor yang disebabkan oleh adanya dinamika pertumbuhan daerah perkotaan, faktor demografi dan ekonomi, yang dijabarkan sebagai berikut :

\section{a. Faktor Demografi}

Dengan semakin bertambahnya penduduk (keturunan), berarti generasi baru memerlukan tempat hidup (tanah) untuk usaha yang diambil dari lahan milik generasi tua atau tanah Negara. Hal ini jelas akan menyempitkan/mengurangi luas tanah disamping adanya keinginan generasi berikutnya merubah lahan pertanian yang sudah ada, meskipun dalam penelitan ini yang memiliki keinginan untuk mengubah fungsi lahan pertanian adalah investor yang membeli lahan tersebut.

\section{b. Faktor Ekonomi}

Pendapatan hasil pertanian masih jauh lebih rendah, karena kalah bersaing dengan yang lain (terutama non-pertanian) antara lain usaha industri, dan wiraswasta. Penggunaan lahan pertanian untuk hortikultura tidak menjanjikan (penghasilan jauh lebih rendah) jika dibandingkan untuk industri dan tempat wisata, disamping usaha holtikultura dianggap melelahkan (lama dan sulit, lebih-lebih jika ada hama/penyakit mengancam) jaminan harganya cenderung rendah saat panen.

Hal inilah yang mendorong mereka tertarik pada usaha lain di luar pertanian, dengan harapan pendapatannya mudah meningkat (walaupun belum keterampilannya masih minim) dengan mengganti lahan pertanian hortikultura menjadi lahan nonpertanian. Tingginya harga yang ditawarkan oleh investor kepada petani, yang jika dibandingkan dengan pendapatan sangat berbeda menjadi faktor yang mendorong petani untuk menjual lahan pertanian dan menyebabkan terjadinya konversi lahan.

\section{Faktor Internal}

Faktor internal jauh lebih melihat sisi yang disebabkan oleh kondisi sosial-ekonomi rumah tangga petani pengguna lahan (Lestari,
2009). Menurut Hartanto (1984), terdapat beberapa karakteristik sosial-ekonomi petani yang sesuai dengan hasil observasi peneliti dilapangan yang dianggap mampu mempengaruhi petani dalam pengambilan keputusan untuk mengalih fungsikan lahan mereka, meliputi :

\section{a. Umur}

Menurut Kartasapoetra (1991), petani yang berusia lanjut akan sulit untuk diberikan pengertian yang dapat mengubah cara berfikir, cara kerja dan cara hidup. Umur petani akan mempengaruhi kemampuan fisik dan respon terhadap hal-hal yang baru dalam menjalankan usaha taninya. Sebagian besar petani di Indonesia berumur sekitar 25 sampai 45 tahun, semakin muda petani, biasanya mempunyai semangat ingin mengetahui yang belum mereka ketahui. Berdasarkan wawancara yang peneliti lakukan dengan beberapa responden yang berusia antara 40-73 tahun, dapat ditarik kesimpulan bahwa rata-rata petani dikawasan obyek wisata yang telah mengalih fungsikan lahan sudah berusia lanjut dan tidak mampu mengolah lahan pertaniannya lagi. Hal ini didukung dengan jawaban dari beberapa responden pemilik lahan tentang alasan "Mengapa Bapak/Ibu setuju dengan harga yang ditawarkan?". Jawaban yang diperoleh peneliti yaitu "karena responden sudah berusia lanjut, dan sudah tidak ada lagi yang ingin mengurus lahan pertanian ini, jadi saya menjualnya" ini juga menunjukan bahwa keinginan generasi muda untuk mengolah lahan pertanian telah menurun.

\section{b. Tingkat pendidikan}

Keterbatasan pengetahuan yang dimiliki petani biasanya akan menjadi hambatan. Tingkat pendidikan petani baik informal, formal maupun non formal akan mempengaruhi cara berfikir yang diterapkan pada usahanya yaitu dalam rasionalisasi usaha dan kemampuan memanfaatkan setiap kesempatan yang ada (Paramitasari, 2010). Berdasarkan data tingkat pendidikan dari responden yang telah mengkonversi lahan pertanian lima (5) diantaranya hanya lulusan SD dan memiliki keterbatasan pengetahuan tentang dampak alih fungsi lahan, hal ini terlihat dari respon informan saat peneliti melakukan wawancara dan hal ini mempengaruhi 
keputusan dalam menjual lahan pertanian tersebut.

\section{c. Pendapatan}

Pendapatan merupakan faktor yang sangat penting dalam menunjang perekonomian keluarga. Tingkat pendapatan merupakan salah satu indikasi sosial ekonomi seseorang dalam masyarakat di samping pekerjaan, kekayaan dan pendidikan. Keputusan seseorang dalam memilih pekerjaan dipengaruhi oleh sumberdaya dan kemampuan dalam diri individu. Responden yang telah mengalihfungsikan lahan pertanian menjadi obyek wisata memiliki pendapatan yang tidak tetap setiap bulannya. Alih fungsi lahan ini tidak mempengaruhi pendapatan per bulan setiap responden, karena lahan bersifat milik keluarga sehingga responden tidak menjadikan lahan ini sebagai sumber pendapatan utama per bulan dan setelah lahan dijual tidak semua responden memanfaatkan hasil penjualan dengan membuka suatu usaha atau membeli lahan baru untuk dikelolah dan meningkatkan pendapatan per bulan.

Peningkatan pendapatan dipengaruhi oleh pengelolaan hasil penjualan lahan pertanian yang telah dimanfaatkan untuk membuka usaha dan memiliki pekerjaan tambahan dilokasi obyek wisata. Sedangkan, salah satu responden mengalami penurunan pendapatan akibat alih fungsi lahan yang terjadi.

\section{d. Kesehatan}

Banyaknya anggota dalam keluarga akan menentukan cara pengelolaan suatu usahatani. Jumlah anggota keluarga yang terlalu banyak akan menyebabkan biaya yang dikeluarkan untuk konsumsi makin besar, biaya mengurus keluarga yang tidak menutup kemungkinan biaya untuk berobat ketika ada anggota keluarga yang sakit semakin meningkat sehingga tidak tersisa untuk biaya pengelolaan pertanian dan mendorong petani untuk mengkonversikan lahannya ( Raharjo, 1999). Faktor ini juga peneliti temukan dilapangan saat mewawancarai seorang informan tentang apa yang mendorong untuk menjual lahan dan di alihfungsikan ? responden 4 mengungkapkan "saat adanya tawaran untuk membeli lahan pertanian miliknya, secara bersamaan suami saya sedang sakit dan membutuhkan biaya untuk berobat. Hal itulah yang mendorong saya untuk menjualnya".

\section{Faktor Kebijakan}

Merupakan aspek regulasi yang dikeluarkan oleh pemerintah pusat maupun daerah yang berkaitan dengan perubahan fungsi lahan pertanian. Kelemahan pada aspek regulasi atau peraturan itu sendiri terutama terkait dengan masalah kekuatan hukum, sanksi pelanggaran dan akurasi objek lahan yang dilarang konservasi. Hasil wawancara dengan perangkat desa Kelurahan Rurukan, dan menurut pemerintah desa "lahan ini merupakan lahan milik pribadi bukan milik pemerintah, jadi pemerintah tidak mengetahui tentang konversi lahan bahkan pemerintah tidak pernah mengeluarkan kebijakan untuk konversi lahan tersebut menjadi kawasan obyek wisata'.

\section{Deskripsi Dampak Alih Fungsi Lahan}

Dampak alih fungsi lahan pertanian menjadi obyek wisata terdiri dari dampak ekonomi, dan dampak sosial budaya baik dari sisi negatif atau positif, terhadap petani dimana dalam penelitian ini petani yang dimaksud adalah yang telah menjual lahan pertaniannya untuk dialih fungsikan.

\section{Dampak Ekonomi}

Menurut Kusudianto dalam Paramitasari, 2010 suatu tempat wisata yang direncanakan dengan baik, tidak hanya meberikan keuntungan ekonomi yang memperbaiki taraf, kualitas dan pola hidup komunitas setempat, tetapi juga peningkatan dan pemeliharaan lingkungan yang lebih baik. Pengembangan Obyek Wisata yang terjadi meningkatkan kunjungan wisatawan dan mengakibatkan adanya peluang bagi masyarakat untuk menunjang perekonomian. Berdasarkan penelitian, teridentifikasi alih fungsi lahan untuk pengembangan kawasan wisata Bukit Rurukan berdampak positif seperti : (1). Meningkatkan pendapatan masyarakat, dengan perkembangan pembangunan kawasan wisata yang terjadi, meningkatkan jumlah wisatawan yang berkunjung ke Kelurahan Rurukan, sehingga membuka peluang bagi masyarakat untuk membuka usaha di sepanjang jalan yang akan dilalui oleh wisatawan maupun di kawasan wisata Bukit Rurukan. Peluang ini jika dimanfaatkan dengan baik akan meningkatkan 
pendapatan dari masyarakat di Kelurahan Rurukan. ; (2). Penyerapan tenaga kerja, pembangunan Obyek Wisata Bukit Rurukan membuka kesempatan kerja bagi masyarakat di Kelurahan Rurukan. Hal ini didukung oleh data yang diperoleh dari pengelolah kawasan wisata bahwa $50 \%$ tenaga kerja yang ada berasal dari Kelurahan Rurukan, baik sebagai karyawan maupun pelaku usaha, dan penyerapan tenaga kerja ini bersifat positif karena ikut mengurangi jumlah pengangguran yang ada di Kelurahan Rurukan ; (3) Peluang berusaha, berdasarkan hasil penelitian dua (2) dari enam (6) responden telah membuka usaha dilokasi wisata Bukit Rurukan dan usaha ini mampu meningkatkan pendapatan mereka, karena dari usaha ini responden yang rata-rata sudah berusia tidak produktif untuk mengelolah usaha pertanian, memperoleh pendapatan yang baru dari usaha yang mereka jalankan. ; (4) Membantu menanggulangi beban pembangunan sarana prasarana, ini dilihat dari keputusan responden yang kehidupan perekonomiannya sebagai petani memiliki pendapatan yang kecil, sehingga tidak mampu memenuhi semua keperluan termasuk dalam pembangunan sarana prasarana mereka atau rumah sebagai tempat tinggal, dengan adanya penjualan lahan yang dilakukan, peneliti menemukan adanya responden yang memanfaatkan hasil penjualan lahan mereka dengan memperbaiki rumah sehingga lebih layak untuk ditempati.

Dengan pengelolaan pembangunan pariwisata yang tepat, dapat memaksimalkan keuntungan dan meminimalkan permasalahan. Penduduk setempat mempunyai peran yang sangat penting dalam upaya pengembangan obyek wisata, karena penduduk setempat mau tidak mau terlibat langsung dalam aktifitasaktifitas yang berkaitan dengan kepariwisataan di daerah tersebut. Akan tetapi apabila suatu obyek wisata tidak dikembangkan atau ditangani dengan baik atau tidak direncanakan dengan matang, dapat menyebabkan kerusakan atau kerugian baik secara ekonomi, maupun sosial budaya (Wibowo, 2007). Hasil penelitian ini menunjukan adanya dampak negatif terhadap aspek ekonomi yaitu : (1) Menurunnya pendapatan petani, dampak ini hanya dirasakan oleh responden yang masih dapat mengolah lahan ini dan juga buruh tani yang memanfaatkan lahan ini sebagai sumber pendapatan. Dari enam (6) responden hanya ada satu (1) responden yang merasakan perubahan pendapatan, sebelum menjual lahan tersebut responden memiliki pendapatan $\pm \mathrm{Rp}$. 2.500.000,- dan setelah lahan ini dijual, responden mengalami perubahan pendapatan sekitar \pm Rp. 1.000.000,- sehingga pendapatan responden menjadi \pm Rp. 1.500.000,-/Bulan.

\section{Dampak Sosial-Budaya}

Menurut Hardinoto, (1996) kebudayaan adalah salah satu daya tarik wisata yang dapat ditunjukan melalui atraksi, yang dapat diidentifikasikan berupa (sumber daya alam, budaya, kehidupan sosial dan sebagainya). Hasil penelitian yang dilakukan memperoleh informasi bahwa pembangunan obyek wisata Bukit Rurukan memberikan beberapa dampak positif terhadap sosial-budaya masyarakat seperti ; (1) Peningkatan pelestarian tradisi dan kesenian tradisional, berdasarkan hasil penelitian dengan adanya pembangunan Kawasan Wisata Bukit Rurukan membuka peluang bagi masyarakat yang biasanya melakukan pertunjukan budaya dengan melakukan pertunjukan di lokasi wisata seperti pertunjukan seni kabasaran, ma'zani, maengket, dan musik bambu. Pertunjukan seni ini juga melibatkan anak-anak dan hal ini secara langsung menjadi sarana pengenalan dan pelestarian budaya terhadap pengunjung yang datang di kawasan wisata, bahkan dapat menumbuhkan kecintaan dan kemauan generasi muda untuk melestarikan kebudayaan Sulawesi Utara. ; (2) Perubahan mata pencaharian, hasil penelitian yang telah dilakukan menunjukan beberapa responden yang sebelumnya memiliki mata pencaharian petani, telah beralih menjadi karyawan dilokasi wisata bahkan ada yang selain mengelolah pertanian memiliki pekerjaan tambahan yaitu ikut terlibat dalam pertunjukan kebudayaan dilokasi wisata. Beberapa petani disekitar kawasan wisata juga memanfaatkan hal ini dengan menjadi tukang parkir, satpam dan pekerjaan lainnya. Faktor yang menyebabkan perubahan mata pencaharian dari petani yaitu pendapatan dari hasil pertanian lebih kecil jika dibandingkan dengan mata pencaharian mereka saat ini.

Suatu pengembangan pariwisata memiliki keterkaitan antara turis/wisatawan, pengelolah kawasan wisata, masyarakat sekitar dan pemimpin masyarakat yang menginginkan hidup yang lebih baik (Paramitasari, 2010). 
Kelestarian budaya dan kehidupan sosial masyarakat lokal akan terus terikikis dengan masuknya wisatawan yang secara terus-menerus membawa kebudayaan dan kehidupan sosial yang tidak sesuai dengan kebudayaan lokal. Peningkatan kesadaran masyarakat lokal terhadap kelestarian budaya dan kehidupan bermasyarakat akan memperkecil dampak negatif pembangunan pariwisata terhadap sosial budaya masyarakat, adapun dampak negatif pembangunan wisata ini, berupa : (1) Meningkatkan kriminalitas masyarakat lokal, berdasarkan wawancara dari responden 6 yang merupakan aparat desa setempat, menyebutkan bahwa dengan adanya obyek wisata ini mengakibatkan sering terjadi keributan antar warga dikawasan wisata dan keributan tersebut berlanjut sampai antar lingkungan. Hal ini tentu merugikan masyarakat yang tinggal disekitar kawasan wisata, hal yang bisa dilakukan adalah pengelolah wisata dapat menjalin kerjasama dengan pemerintah/ aparat Kelurahan Rurukan, karena tanggungjawab keamanan bukan hanya pengelolah tapi masyarakat Keluraha Rurukan. ; (2) Terkikisnya nilai budaya dan norma masyarakat, hasil observasi yang peneliti lakukan di lokasi wisata dapat disimpulkan bahwa dengan meningkatnya pengunjung yang datang dilokasi wisata secara tak langsung memberi dampak negatif terhadap nilai budaya dan norma masyarakat, hal ini dilihat dari gaya pakaian, gaya bicara bahkan kebiasaan-kebiasaan masyarakat modern yang bersifat negatif dari pengunjung yang datang dilokasi wisata, dan jika terus dibiarkan hal ini akan membawa perubahan kepada masyarakat lokal yang ada disekitar kawasan wisata, yang akan menganggap hal tersebut sebagai suatu kebiasaan.

\section{KESIMPULAN DAN SARAN}

\section{Kesimpulan}

Berdasarkan hasil penelitian dapat disimpulkan bahwa terjadinya konversi lahan dipengaruhi oleh harga lahan yang tinggi dan sebagian responden dapat memanfaatkan hasil penjualan untuk membuka usaha baru yang dapat meningkatkan pendapatan. Beberapa responden tidak mengalami perubahan pendapatan akibat lahan yang telah dijual karena lahan ini bersifat milik keluarga atau warisan, sehingga dalam pengelolaannya harus dibagi begitu juga hasil penjualan.
Alih fungsi lahan yang terjadi juga memberi dampak positif terhadap penyerapan tenaga kerja, karena mayoritas pekerja dan pelaku usaha di kawasan wisata adalah masyarakat yang berasal dari Desa Rurukan, hal ini memberi dampak positif terhadap pendapatan masyarakat. Dengan adanya atraksiatraksi kesenian dan kebudayaan yang sering digelar di kawasan wisata Bukit Rurukan dapat menjadi sarana promosi atau pengenalan bagi wisatawan bahkan menumbuhkan semangat bagi generasi muda untuk melestarikan kebudayaan Sulawesi Utara.

Adanya pembangunan kawasan wisata Bukit Rurukan selain berdampak positif juga memiliki dampak negatif. Terlihat dari kondisi sosial budaya masyarakat setempat. Berdasarkan hasil penelitian dampak negatif berupa sering terjadinya keributan di lokasi wisata, meningkatnya kriminalitas serta terkikisnya norma dan budaya masyarakat lokal dengan banyaknya wisatawan luar yang berkunjung.

\section{Sebaiknya $\begin{gathered}\text { Saran } \\ \text { dalam pengembangan }\end{gathered}$} kawasan wisata Bukit Rurukan yang perlu diperhatikan adalah pengaturan kembali pedagang-pedagang yang ada di kawasan wisata dengan memprioritaskan petani yng telah menjual lahan pertanian untuk dialih fungsikan menjadi obyek wisata. Pengelolah wisata dapat menjalin kerjasama dengan pemerintah Desa Rurukan untuk bersama-sama dalam menjaga keamanan dan ketertiban di lokasi wisata, sehingga dapat mengurangi bahkan mengantisipasi dampak negatif dari pembangunan kawasan wisata Bukit Rurukan.

\section{DAFTAR PUSTAKA}

Diniyati, 2001. Dinamika Kelompok Tani Hutan Rakyat: Studi Kasus di Desa Kertayasa, Boja dan Sukorejo.Jurnal Kehutanan2.4 .

Gibson dan Donnelly, 2006. Organisasi dan Manajemen : Perilaku, Struktur dan Proses. Erlangga : Jakara. 
Hutauruk, Erwin Hasudungan 2009. Pengaruh Pendidikan Dan Pengalaman Petani Terhadap Tingkat Produktivitas Tanaman Kopi Dan Kontribusinya Terhadap Pengembangan Wilayah Di Kabupaten Tapanuli Utara. Skripsi.

Mardikanto, L. 2009. Sistem Penyuluhan Pertanian. Sebelas Maret University Press: Surakarta.

Mayasari, dan Nangameka 2015. Pengaruh Keberadaan Kelompok Tani Terhadap Pendapatan Usaha Tani Tembakau (Studi Kasus di Desa Tlogosari Kecamatan Sumbermalang).

Nuryanti, Sri, dan Swastika. Peran Kelompok Tani dalam Penerapan Teknologi Pertanian.Forum Penelitian Agro Ekonomi.Vol. 29.No. 2. 2011.

Santoso, S. 2004. Dinamika Kelompok (revisi). Bumi Askara ISBN: 979526964x

Setiadi, H. 2005. Faktor-faktor yang Mempengaruhi Anggota Kelompoktani dalam Berusahatani (Kasus Usahatani Ikan Tawar di Desa Purwasari Kabupaten Darmaga Bogor, Jawa Barat).Tesis.Bogor : IPB.
Slamet, M. 2001. Paradigma Penyuluhan Pertanian dalam Era Otonomi Daerah.Makalah Pelatihan Penyuluhan Pertanian di Universitas Andalas.

Soedarsono, T. 2005. Dinamika Kelompok. Universitas Terbuka: Jakarta

Soekanto, S. 2006. Sosiologi Suatu Pengantar. PT. Raja Grafindo Persada cetakan ke30: Jakarta. 2002. Kumpulan Bahan Kuliah : Kelompok, Organisasi dan Kepemimpinan.IPB: Bogor

Suhardiyono . 1992. Penyuluhan : Petunjuk bagi Penyuluh Pertanian. Erlangga: Jakarta

Tampubolon, Joyakin, et al 2016. "Pemberdayaan Masyarakat Melalui Pendekatan Kelompok (Kasus Pemberdayaan Masyarakat Miskin melalui Pendekatan Kelompok Usaha Bersama (KUBE))." Jurnal Penyuluhan 2.2. 